\title{
Chinese Foreign Exchange Reserves, Policy Choices, and the U.S. Economy
}

Christopher J. Neely

China is both a major trading partner of the United States and the largest official holder of U.S. assets in the world. The value of Chinese foreign exchange reserves peaked at just over $\$ 4$ trillion in June 2014 but has since declined to $\$ 3.19$ trillion (as of August 2016). This very large decline in foreign exchange reserves is unprecedented, and some analysts have speculated that continued sales of these (mostly U.S.) assets might significantly impact the U.S. and global economies. This article explains the reasons for this large decline in official assets, China's available policy choices, and how these choices could affect the U.S. economy. (JEL E52, E58 F31, F32)

Federal Reserve Bank of St. Louis Review, Second Quarter 2017, 99(2), pp. 207-31. https://doi.org/10.20955/r.2017.207-231

"It [2008] was a time of a financial crisis and a bear market... But now the root cause is basically China. So, a hard landing [in China] is practically unavoidable."

-George Soros $\underline{1}$

“Think Twice Before Declaring War on Chinese Currency."

- Mei Xinyu ${ }^{2}$

\section{INTRODUCTION}

The U.S. and Chinese economies trade a great deal in goods, services, and assets. China is the source of the largest share of U.S. imports and the destination for the third-largest share of U.S. exports (Figure 1). China has also become increasing important financially. In particular, the Chinese government has the largest foreign exchange reserves in the world, which are assets (usually bonds) held by a central bank or other government agency that are liabilities of some foreign entity. Although the exact composition of the Chinese foreign exchange reserves is confidential, observers estimate that about 67 percent of the value consists of dollardenominated assets, mostly U.S. Treasury securities, but also many U.S. agency and corporate

Christopher J. Neely is an assistant vice president and economist at the Federal Reserve Bank of St. Louis. The author thanks Yi Li Chien, Michael McCracken, and Scott Wolla for helpful comments and Evan Karson for research assistance.

(c) 2017, Federal Reserve Bank of St. Louis. The views expressed in this article are those of the author(s) and do not necessarily reflect the views of the Federal Reserve System, the Board of Governors, or the regional Federal Reserve Banks. Articles may be reprinted, reproduced, published, distributed, displayed, and transmitted in their entirety if copyright notice, author name(s), and full citation are included. Abstracts, synopses, and other derivative works may be made only with prior written permission of the Federal Reserve Bank of St. Louis. 


\section{Figure 1}

\section{U.S. Trading Partners}

Top Five Trading Partners: Exports

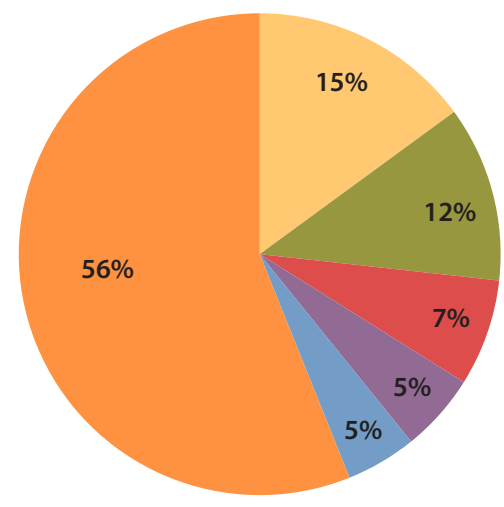

Top Five Trading Partners: Imports

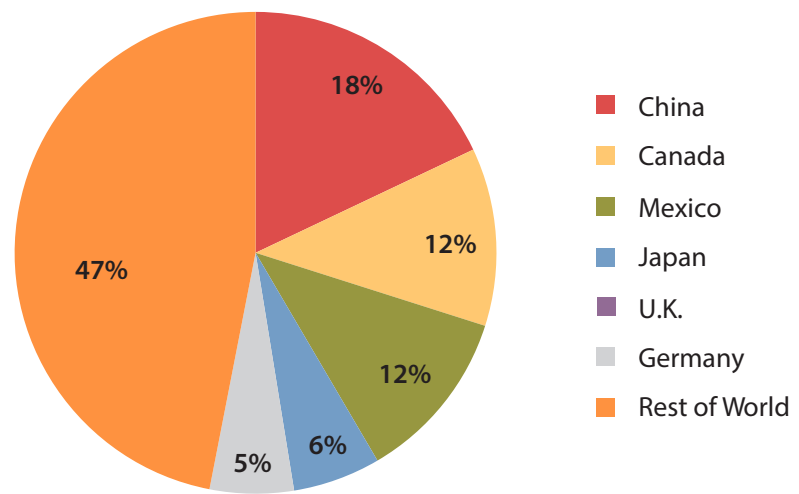

NOTE: The left panel displays the top destinations for U.S. exports, as a percentage of total U.S. exports, in 2015. The right panel displays the analogous figures for sources of U.S. imports in 2015.

SOURCE: Bureau of Economic Analysis (BEA), U.S. Census Bureau, and Haver Analytics.

bonds. The top-left panel of Figure 2 illustrates the estimated currency composition of Chinese reserves (Wildau, 2014). The top-right panel of Figure 2 shows that China holds the largest foreign exchange reserves in the world, by far. Thus, the U.S. and Chinese economies have important trade and financial links.

The bottom panel of Figure 2 shows, however, the value of Chinese foreign exchange reserves peaked at just over $\$ 4$ trillion in June 2014 and has since declined to $\$ 3.12$ trillion (as of October 2016). $\underline{3}$ Although China retains very large foreign exchange reserves-in excess of $\$ 3$ trillion as of October 2016-this very large and rapid decline in Chinese foreign exchange reserves, most of which are denominated in U.S. dollars (USD), is unprecedented. Indeed, this disturbingly rapid decline in Chinese reserves prompted well-known financier George Soros (2016) to predict a "hard landing" for the Chinese economy. In response to this ominous prediction, an opinion piece in the Chinese authorities' People's Daily warned 'Soros's war on the renminbi and the Hong Kong dollar cannot possibly succeed-about this there can be no doubt" (Wildau, 2016b). This war of words between the most famous currency speculator in the world and the Chinese authorities strongly suggests that the rest of this interconnected world should understand the situation and its potential implications. This article explains how this situation came about, China's available policy choices, and how these choices could affect the U.S. economy.

The next section of the article discusses managed exchange rates, the role of financial regulation in the context of the Chinese exchange rate management, and China's accumulation of foreign exchange reserves. Section 3 discusses China's policy options and their potential effects on the U.S. economy. Section 4 concludes. 


\section{Figure 2}

\section{Foreign Exchange Reserves}

Currency Composition of Chinese Foreign Exchange Reserves (September 30, 2014)

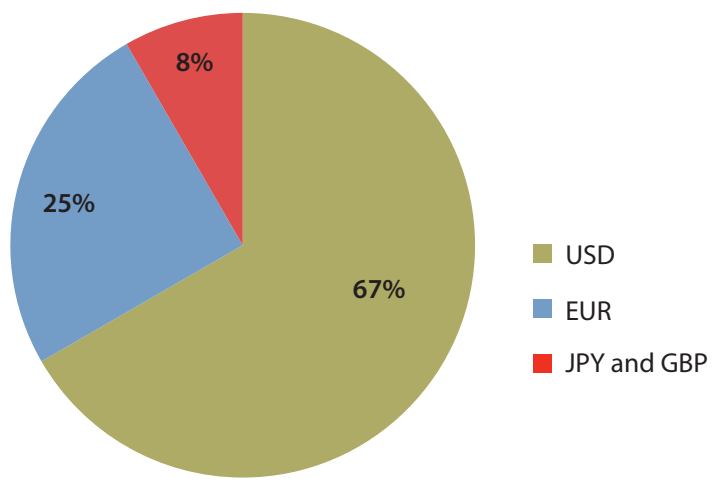

Holders of Foreign Exchange Reserves in Trillions of USD (December 2015)

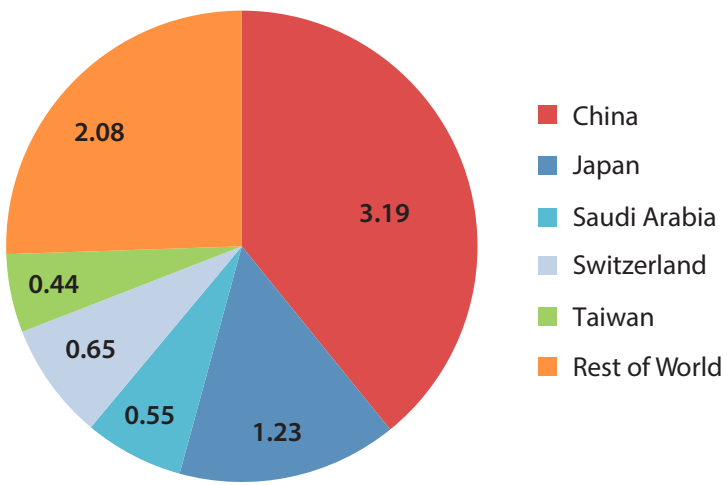

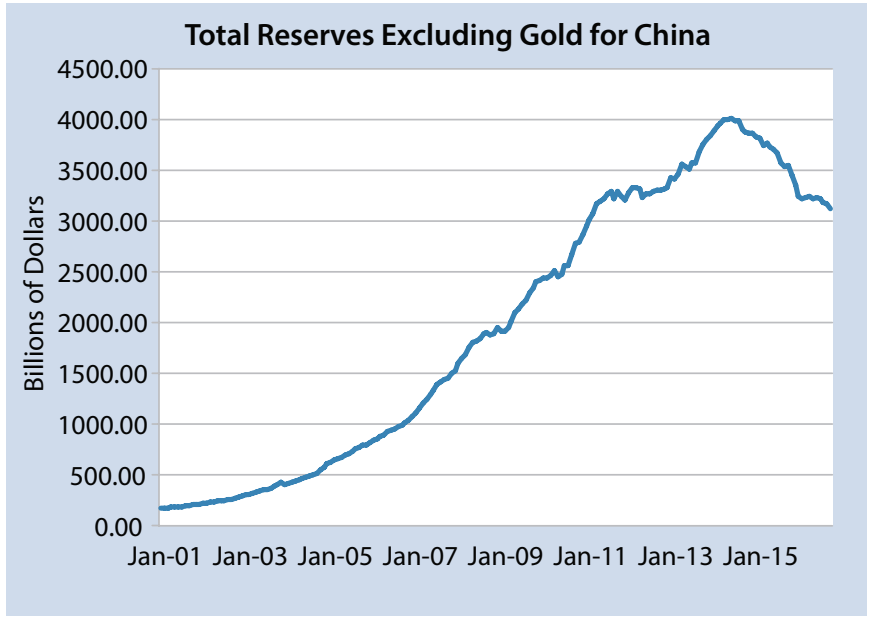

NOTE: The figure displays the currency composition of Chinese reserves (top-left panel), the size of foreign exchange reserves in trillions of USD for major holders (top-right panel), and the time series of the value of Chinese foreign exchange reserves in billions of USD from January 2001 to October 2016 (bottom panel). EUR, euro. JPY, Japanese yen. GBP, British pound.

SOURCE: Top-left panel: Financial Times. Top right panel: International Monetary Fund and Haver Analytics. Bottom panel: International Monetary Fund and FRED ${ }^{\oplus}$, Federal Reserve Bank of St. Louis; https://fred.stlouisfed.org/series/TRESEGCNM052N, accessed November 30, 2016.

\section{CHINA'S MANAGED EXCHANGE RATE}

\subsection{Managed Exchange Rates}

Every country with its own currency must choose the extent to which it manages the external value of its currency against other currencies. This strategy is often referred to as an "exchange rate regime." A managed exchange rate regime denotes a promise by a government or monetary authority to maintain the value of its currency by changing policy-mainly 
monetary policy - and trading foreign exchange reserves. Such a commitment is contingent on economic circumstances, of course; governments frequently renounce or modify such arrangements. Exchange rate regimes in which the government has no such obligation are called floating or flexible regimes.

Managed exchange rates are common. The International Monetary Fund (IMF, 2014) estimates that 66 percent of exchange rate arrangements are managed, leaving only about 34 percent of such arrangements as floating. $\underline{4}$ Most countries that choose to float their currencies are developed. For example, the currencies of Australia, Canada, Japan, the United States, and the European Monetary Union are freely floating in the sense that their central banks do not claim to maintain some foreign exchange value for the domestic currency. Of course, the central banks of these nations may consider the value of their currencies in monetary policy deliberations. In contrast, most emerging markets highly regulate their financial sectors, along with some sort of explicit management, to meet their exchange rate targets. Emerging market authorities choose to manage their exchange rates partly to facilitate planning for businesses that import or export or use international financial markets. Governments in developed economies see less need for exchange rate management because businesses in those markets can more easily insulate themselves from exchange rate fluctuations with futures and options contracts.

In addition, governments might manage the exchange rate for other reasons. For example, managed exchange rates can also assist policymakers by anchoring the domestic price level to an objective "nominal peg," thereby helping to control inflation expectations (see Neely, 1996). Governments can also use a managed exchange rate regime to influence the relative prices of domestic versus foreign goods. This is discussed further in Section 2.3.

The chief disadvantage of exchange rate management is that it requires the authorities to employ policy tools to manage the exchange rate and the use of such tools has costs. Generally speaking, governments can influence prices, such as exchange rates, in at least two ways. First, a government can use market forces to affect prices, such as the U.S. government does when it buys agricultural output to support food prices or as the Federal Reserve does when it buys and sells securities to affect interest rates. Second, governments can regulate the price or quantity that may be sold, as governments do with minimum wages or the auto import quotas of the 1980s.

Governments can also direct the central bank to use market forces-transactions in domestic bonds or foreign exchange-to manage the exchange rate. $\frac{5}{}$ For example, if the value of the domestic currency threatens to decline below some desired level, the central bank can sell domestic bonds to the public, which will reduce the domestic money supply and raise domestic interest rates, all else equal. Equivalently, the central bank can directly purchase its own currency with foreign exchange reserves. In either case, the domestic interest rate will tend to rise and the foreign exchange value of the domestic currency will tend to increase. The chief cost of this method is that monetary policy then cannot be used to meet other goals, such as stable prices or full employment. If the desired exchange rate is incompatible with domestic objectives, such as full employment or stable prices, then the government must choose which goal to pursue. 
Because governments are unhappy with the idea that they must give up control of monetary policy to control the exchange rate, they often try to "sterilize" the effect of their actions on the domestic money supply. For example, if the central bank is buying its own currency in foreign exchange markets-reducing the money supply_it might sterilize this action by simultaneously buying domestic bonds, which increases the money supply. Sterilization is an important policy because failure to sterilize would mean that foreign reserve sales would tighten monetary policy, raise interest rates, and slow the economy.

Sterilized foreign exchange intervention, however, doesn't change economic fundamentals and so must be supplemented with financial regulations in the form of exchange controls and capital controls. Capital controls are taxes or restrictions on international transactions in assets such as stocks or bonds. Exchange controls are capital controls that are applied specifically to foreign exchange. Sometimes governments even use such regulations as the primary method to manage the exchange rate. The presumed cost of exchange and capital controls is that they restrict beneficial transactions and distort economic activity. For example, capital controls that prohibit domestic residents from holding foreign assets leave those domestic residents with asset portfolios that have lower expected returns, greater exposure to risk, or both. For sterilized intervention to be effective in controlling exchange rates, exchange controls and/or capital controls must be fairly effective.

The conventional wisdom of the economics profession has been that capital controls are ineffective and impose substantial costs. That generalization is simplistic, however; it ignores distinctions among types of capital controls and varied criteria for success (Neely, 1999). In a country such as China, in which the government is willing and able to rigorously enforce capital controls on both inflows and outflows and which maintains substantial control over the domestic financial system, capital controls are more likely to be effective (Minton, 1999). $\underline{6}$

\subsection{Tools of China's Exchange Rate Management}

In recent decades, the Chinese authorities have maintained a managed, or fixed, exchange rate that they see as facilitating export-led growth. Like many other emerging markets, China has traditionally had a very highly regulated financial system and its authorities have used broad capital and exchange controls to maintain the value of the Chinese yuan (CNY) in its managed exchange rate system. $\underline{7}$ These capital controls are intended to reduce the volatility of flows and to skew the composition of the flows toward foreign direct investment, which the Chinese government reportedly sees as being stable and encouraging technology transfer. The Chinese authorities believe that the experience of the Asian currency crisis of 1997 illustrates the necessity of maintaining a relatively regulated international financial sector (Xiao and Kimball, 2006, and Wildau, 2016b). In that episode, capital outflows destabilized other Asian economies, particularly those of Indonesia, South Korea, and Thailand.

To maintain a stable international financial sector, the Chinese government regulates both domestic purchases of foreign assets (capital outflows) and foreign purchases of domestic assets (capital inflows). The outflow controls are more important because these prevent shifts to foreign assets (i.e., sales of CNY) that might force a devaluation of the CNY. Controls of inflows are also important, however, because regulating inflows implicitly reduces the amount of "hot money" that is likely to be moved into non-Chinese assets in a crisis and thereby facili- 
Figure 3

The CNY/USD Exchange Rate (January 2001-November 2016)

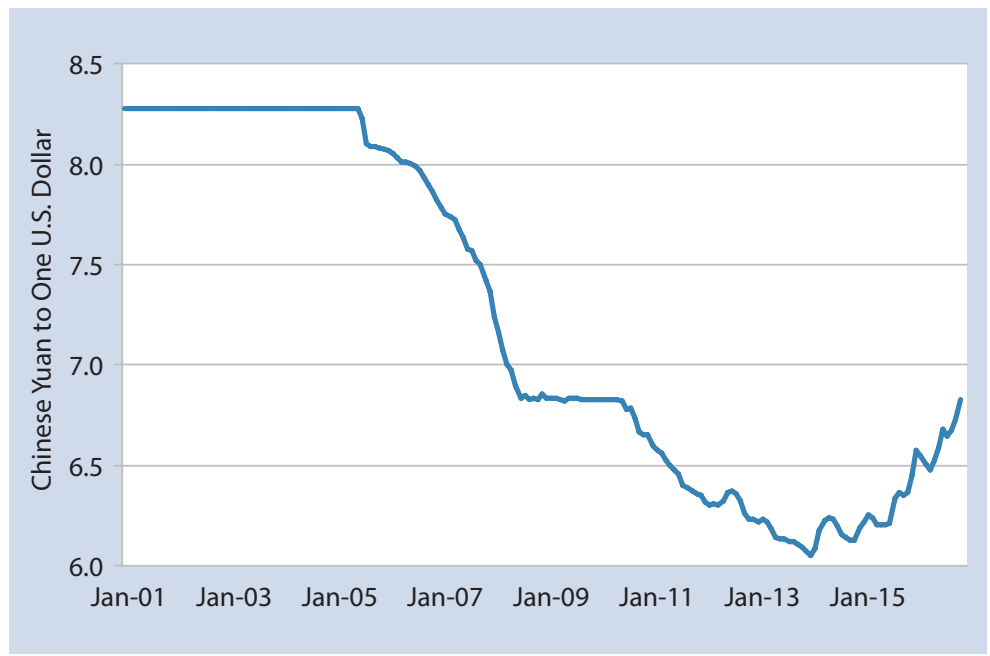

NOTE: The figure displays the time series of the CNY/USD exchange rate from January 2001 to November 2016. An increase in this exchange rate denotes an appreciation of the USD or depreciation of the CNY.

SOURCE: Board of Governors of the Federal Reserve System and FRED ${ }^{\circledR}$, Federal Reserve Bank of St. Louis; https://fred.stlouisfed.org/series/EXCHUS, accessed November 30, 2016.

tates the controls on outflows. Controls on capital outflows permit lower interest rates and higher money growth than otherwise would be possible (Marston, 1995).

Chinese capital controls require all onshore foreign exchange transactions to be conducted at designated foreign exchange banks (Xiao and Kimball, 2006). Current account transactions in spot, forward, and swap markets are permitted, but most capital account transactions are prohibited. $\underline{8}$ Chinese residents may purchase up to $\$ 50,000$ worth of foreign exchange per year, an amount adequate to travel extensively or send one's child to a university abroad, especially when allowances are pooled across family members (Wildau, 2016a).

China's policies have maintained a stable exchange rate over a period of decades. Figure 3 illustrates the relatively stable path of the CNY/USD exchange rate from January 2001 to November 2016. Although China trades with many countries, the USD has figured prominently in Chinese exchange rate management. Prior to 2006, the Chinese authorities kept the CNY rigidly fixed to the USD because of the importance of the United States as an export destination and the importance of the USD in international finance. Since 2006, the Chinese authorities have permitted greater flexibility in the external value of the CNY, although its value has still been far more stable than that of floating currencies such as the dollar, the British pound (GBP), the euro (EUR), or the Japanese yen (JPY).

The price of a stable exchange rate can be unstable short-term interest rates. This is because, in the absence of strong capital controls, monetary policy can stabilize either interest rates or exchange rates, but not both. ${ }^{9}$ Despite the stability in the external value of the CNY 


\section{Figure 4}

\section{Chinese Short-Term Interest Rates (April 1990-November 2016)}

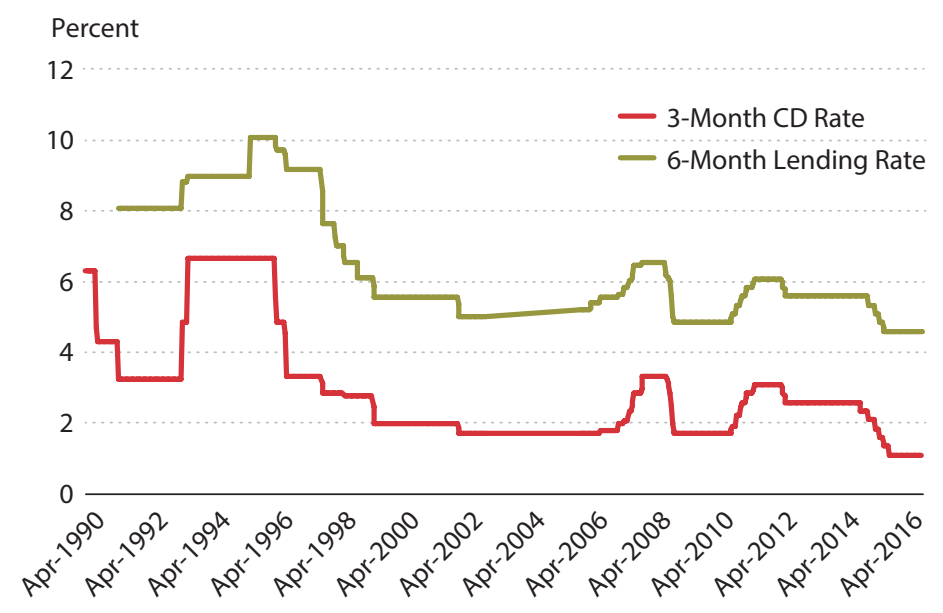

NOTE: The figure displays the time series of two Chinese money market interest rates: the 3-month CD rate and the 6-month lending rate. $C D$, certificate of deposit.

SOURCE: People's Bank of China, Tullett Prebon Information, National Interbank Funding Center, and Haver Analytics.

(see Figure 3), Figure 4 illustrates that Chinese short-term interest rates have also been fairly steady over the past 20 years, which indicates that financial regulations have probably been effective in maintaining some freedom for domestic monetary policy. In other words, China's capital controls have allowed the country to manage the exchange rate while retaining greater independence for domestic monetary policy to meet internal goals for employment and inflation. $\underline{10}$

\subsection{A Brief History of China's Exchange Rate Management}

China has used monetary policy and capital controls to closely manage the external value of the CNY, especially with respect to the USD. At the same time, China has run a hefty trade surplus with the rest of the world, in particular with the United States. Prior to 2006, American politicians understandably often linked these two facts, criticizing China for "currency manipulation," blaming Chinese trade surplus with the United States on the level of the exchange rate, and demanding that the CNY be revalued against the dollar.

The level of the exchange rate is potentially important for trade because-holding the respective national price levels constant-the exchange rate changes the relative prices of tradable goods. A higher value of the CNY/USD, for example, makes Chinese goods cheaper compared with their U.S. counterparts, making it more difficult for the U.S. firms to compete in common markets. Figure 5 illustrates the real (inflation-adjusted) depreciation of the CNY versus the JPY, the Korean won (KRW), and the USD since January 2000. The real value of the CNY versus the currencies of these major trading partners has been relatively stable compared with the real value of the USD versus other major floating rate currencies, such as the EUR, the JPY, and the GBP. 


\section{Figure 5}

Real Value of the CNY versus the JPY, KRW, and USD (January 2000-October 2016)

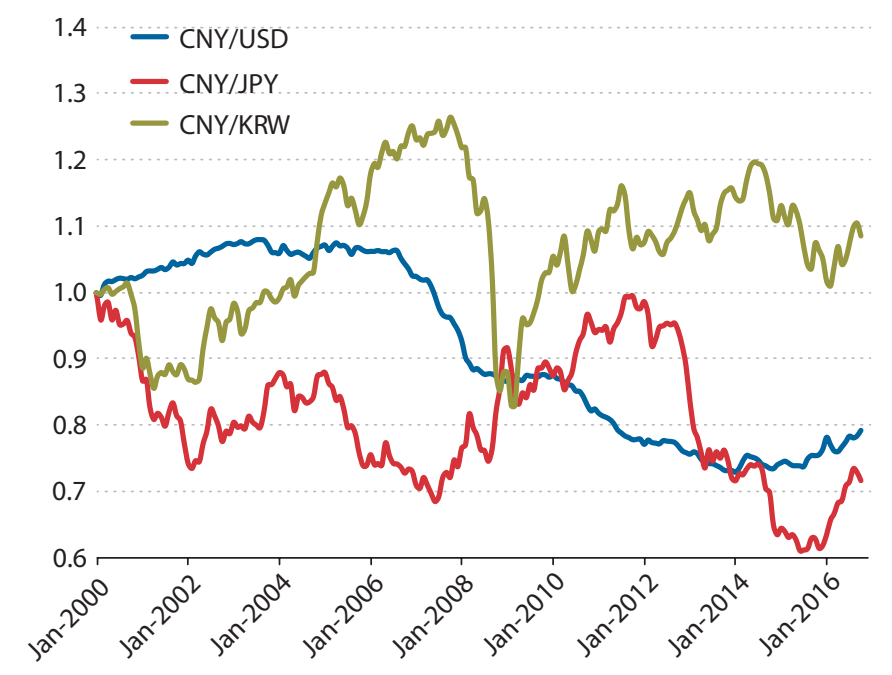

NOTE: The figure displays the time series of the real (inflation-adjusted) value of the CNY versus the JPY, KRW, and USD from January 2000 through October 2016. An increase in this exchange rate denotes a real appreciation of the non-CNY currency or, equivalently, a real depreciation of the CNY. The real exchange rates are normalized to equal 1 in January 2000.

SOURCE: Board of Governors of the Federal Reserve System and OECD.

In 2005, Senator Charles Schumer cited estimates that the CNY was 15 to 40 percent undervalued in proposing a bill, with Senator Lindsey Graham, to impose a compensating 27.5 percent tariff on Chinese goods (Fox News, 2006). 11 China placated these U.S. complaints to a certain extent, when, on July 21, 2005, it announced a 2.1 percent one-off revaluation of the $\mathrm{CNY}$ versus the USD and a new exchange rate mechanism in which the CNY would no longer be fixed solely against the USD but against a basket of currencies, whose exact composition was not announced (Spiegel, 2005). China revealed, however, that the USD, the EUR, the JPY, and the KRW would be the major components of the basket and that the Singapore dollar (SGD), the Malaysian ringgit (MYR), the Russian ruble (RUB), the Australian dollar (AUD), the Thai baht (THB), and the Canadian dollar (CAD) would also be included. Figure 5 shows that the real (inflation-adjusted) value of the CNY against the USD has increased since 2005.

Although China has had a highly regulated financial system, the authorities have sought to reduce the amount of regulation to make the CNY more widely used internationally. In late 2008, the Chinese authorities began to take steps toward making the CNY a fully convertiblethat is, freely tradable-currency and they opened up the offshore foreign exchange market (CNH). In June 2010, the People's Bank of China (PBOC), China's central bank, made further reforms to increase the CNY's exchange rate flexibility. $\underline{12}$ These deregulatory moves were part of a Chinese campaign for inclusion in the special drawing rights (SDR) basket (Cendrowski, 2015). An IMF condition of inclusion in the basket is that China would liberalize some capital 


\section{Figure 6}

\section{Chinese Exports and Imports as a Percent of GDP}

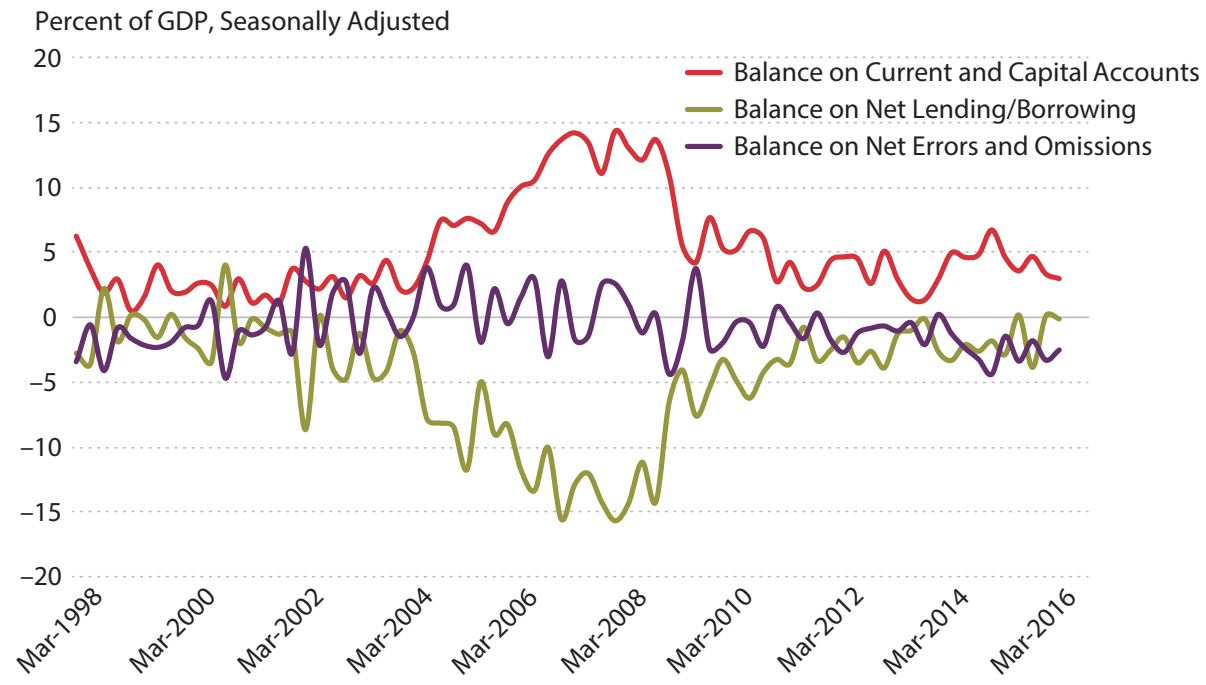

Percent of GDP, Seasonally Adjusted

8

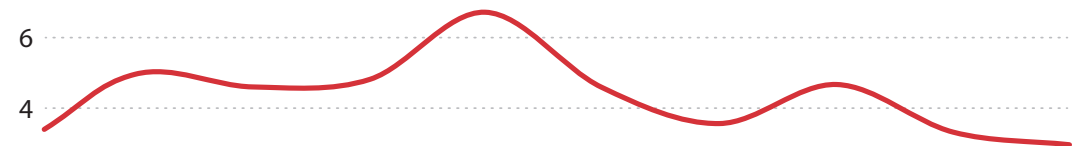

2
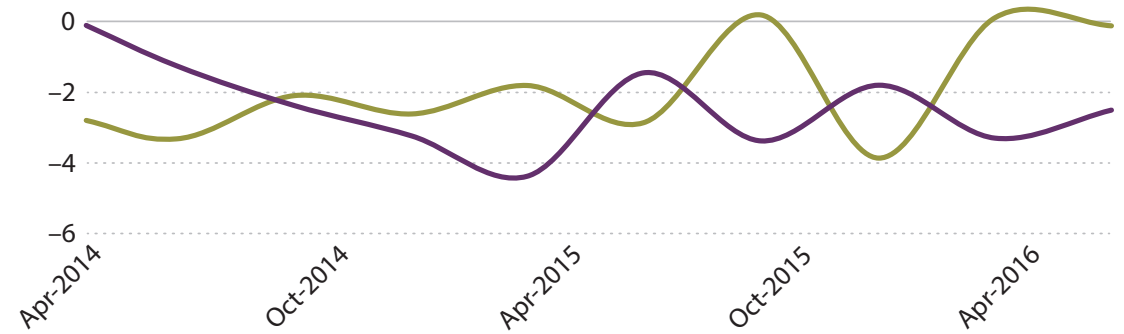

NOTE: The top panel displays balances on the sum of Chinese current and capital accounts, the financial account (net lending/borrowing), and errors and omissions as percentages of GDP, from March 1998 through June 2016. The lower panel displays the same data from March 2014 through June 2016 for clarity.

SOURCE: State Administration of Foreign Exchange, China National Bureau of Statistics, and Haver Analytics.

controls (Bradsher, 2015). Specifically, one shibboleth is that a currency should be "freely usable" (IMF, 2015). In particular, the Chinese were anxious to get the CNY into the SDR basket in 2015 as the next opportunity for inclusion would not arrive until 2020 (Bradsher, 2015). These desires played into further reductions in capital controls and the surprise August 2015 devaluation of the CNY by 4.4 percent. Although this devaluation was intended to reduce 
downward pressure on the CNY and thereby reduce the need for capital controls, it may have increased expectations of future devaluations and thereby increased pressure on the CNY.

\subsection{China's Foreign Exchange Reserves}

During the 1990s and 2000s, China grew rapidly and became a very important trading nation. A country with a very high domestic savings rate must direct those savings toward some combination of domestic investment (residential or capital goods) or the accumulation of foreign assets. That is, the domestic savings would establish claims on future consumption, either from domestic or foreign sources. In China's case, the savings created a large current account surplus and a corresponding capital account deficit that contributed to foreign exchange reserve accumulation (top panel of Figure 6). 13 Mechanically speaking, Chinese firms would sell goods and services abroad in exchange for foreign currency and then would sell that foreign currency for $\mathrm{CNY}$ through the Chinese banking system. The PBOC would then buy the foreign exchange with CNY from the banks and use the foreign exchange to buy international sovereign and corporate bonds, which would be held as foreign exchange reserves.

An accumulation of foreign assets is the natural consequence of the current account surpluses that China ran during this period. $\underline{14}$ Chinese authorities could have established policies that would have instead funneled excess savings to either domestic investment-that is, importing capital goods-or to private accumulation of foreign assets, such as foreign equities, bonds, or direct investment abroad. Instead, the capital controls and other policy choices of Chinese authorities meant that financial account surpluses would accumulate as internationally denominated bonds held by those authorities-that is, as foreign exchange reserves (see Figure 2).

Foreign exchange reserves exhibit both advantages and disadvantages compared with other forms of asset holdings. The chief disadvantage is that they pay a relatively low rate of return because they consist almost entirely of very safe sovereign debt and high-grade corporate bonds. On the other hand, foreign exchange reserves are very liquid and the government has direct control over them, allowing them to be used at its discretion in case of sudden need, such as in response to a natural disaster or a domestic financial crisis. $\frac{15}{5}$ These characteristics allow the authorities to use the foreign exchange reserves to defend the domestic currency against speculative attack or to recapitalize the domestic banking system in case of a financial crisis (Wen, 2011a). The Asian currency crisis of 1997 might have motivated the Chinese authorities to prepare in earnest for another financial crisis (Xiao and Kimball, 2006, and Wildau, 2016b). The ability to respond quickly and strongly to such financial needs gives the Chinese authorities credibility with financial markets, making it less likely that they will be needed.

\subsection{Why Have Reserves Declined Since June 2014?}

Prior to the financial crisis of 2008-09, Chinese exports grew consistently and strongly for decades. Figure 7 shows that after peaking in 2008, however, Chinese exports and imports, as percentages of gross domestic product (GDP), generally declined from 2009-15. By 2012, analysts were reducing their estimates of Chinese growth. Figure 8 illustrates that mid-year Organisation for Economic Co-operation and Development (OECD) forecasts of Chinese 


\section{Figure 7}

\section{Chinese Exports and Imports as a Percent of GDP (1992-2015)}

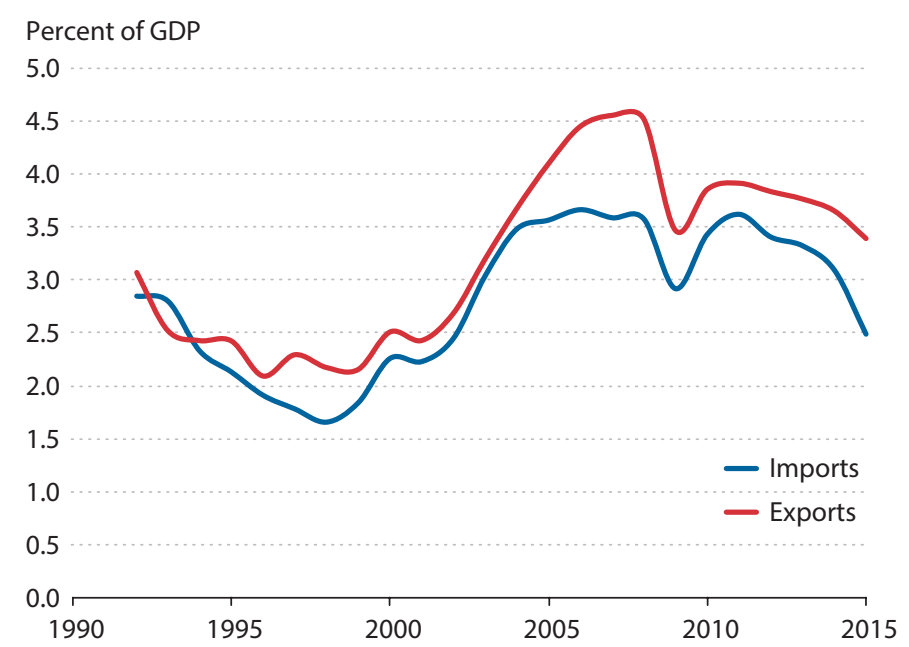

NOTE: The figure displays balances on Chinese exports and imports as percentages of Chinese GDP from 1992 through 2015.

SOURCE: OECD and Haver Analytics.

\section{Figure 8}

Mid-Year OECD Forecasts of Chinese GDP Growth for the Following Calendar Year (2006-16)

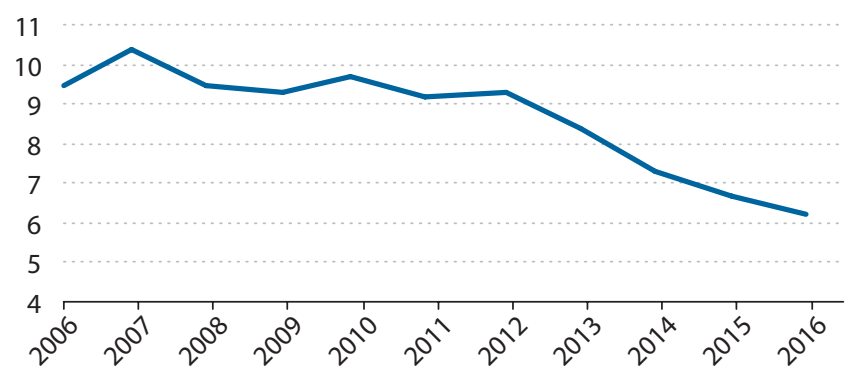

NOTE: The figure displays one-year-ahead OECD forecasts of Chinese GDP growth from 2006 through 2016. SOURCE: OECD.

GDP growth for the following calendar year-although still very strong by almost any standards-have been declining since 2007 and have been falling faster since 2012. The declines in forecasted real growth naturally reduced forecasts for interest rates and demand for the renminbi (CNY). At the same time, the bottom panel of Figure 2 shows that Chinese foreign exchange reserve growth first slowed in 2012-13 and then reversed in 2014. This decline in reserves means that, since June 2014, the PBOC has been selling dollars and buying CNY to 
Figure 9

Balances on Subaccounts of the Chinese Financial Account as a Percent of GDP

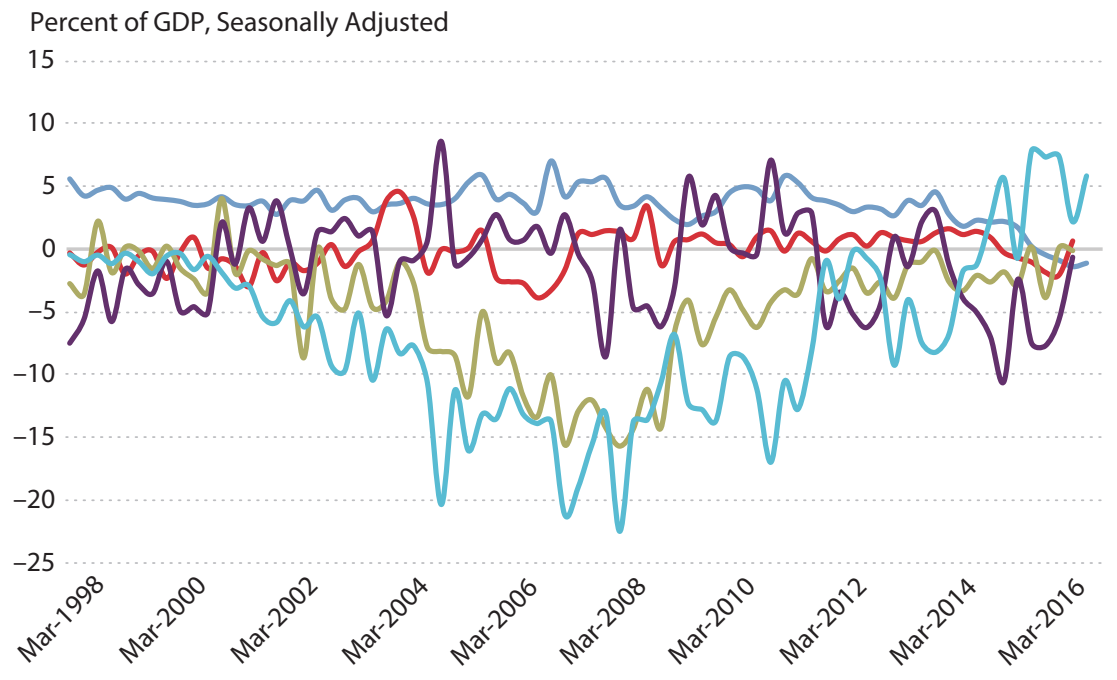

Percent of GDP, Seasonally Adjusted

10

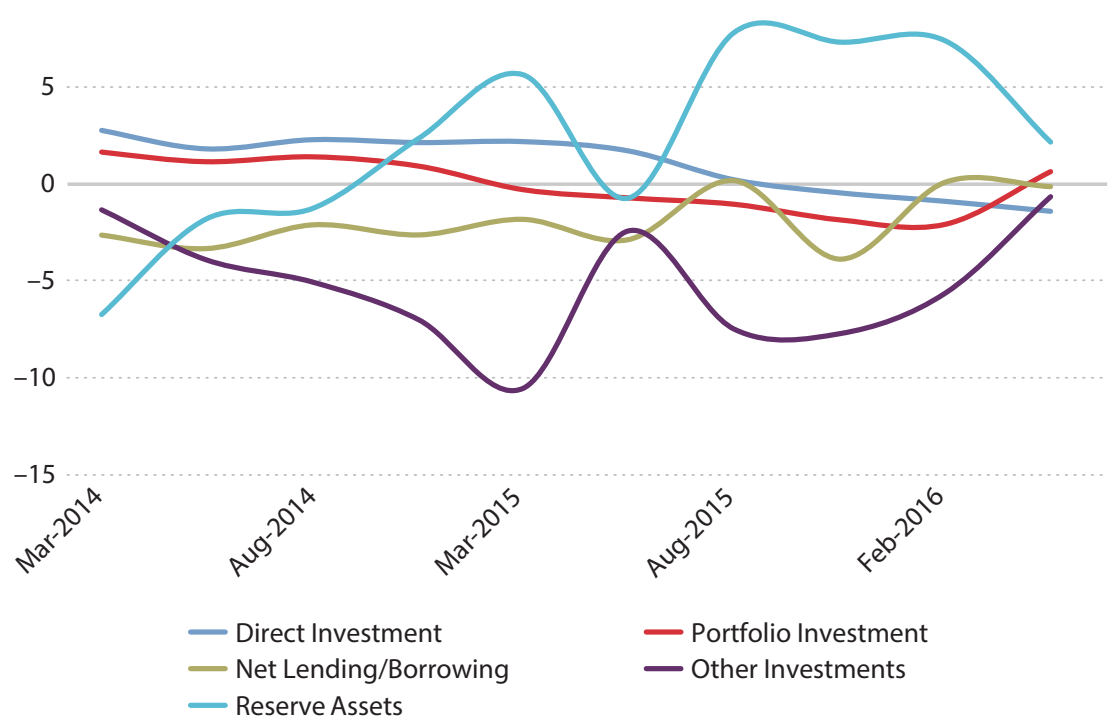

NOTE: The figure displays the balances as percentages of GDP on the following international accounts of China: direct investment, portfolio investment, other investments, reserve assets, and net lending/borrowing (i.e., the total financial account). The top panel displays the data from March 1998 through September 2016, and the bottom panel displays the same data from March 2014 through June 2016.

SOURCE: State Administration of Foreign Exchange, China National Bureau of Statistics, and Haver Analytics. 
maintain the domestic currency's value. $\frac{16}{}$ These foreign exchange sales have reduced China's foreign exchange reserves substantially_falling over $\$ 800$ billion from June 2014 to August 2016.

What has caused Chinese reserves to decline? As a matter of accounting, the balance on the Chinese financial account must equal that on the combined current and capital accounts. Therefore, if one component of the financial account-foreign exchange reserve accumulation-declines and becomes negative, then either the current account must have gone into deficit or another financial account must have increased.

The bottom panel of Figure 6 shows a healthy surplus in the Chinese current account in recent years, generally between 2 and 4 percent of GDP. Therefore, we can rule out the idea that the decline in reserves is due to a simple reversal of the current account surplus conditions that led to reserve accumulation. Instead, it seems necessary that some elements of the financial account must have become positive. The bottom panel of Figure 9 confirms that the balances on direct investment, portfolio investment, and other investments have become more negative, with the balance on "other investments" covarying very negatively with the balance on reserve assets.

The IMF (2013, p. 111) defines "other investments" as follows:

Other investment is a residual category that includes positions and transactions other
than those included in direct investment, portfolio investment, financial derivatives and
employee stock options, and reserve assets. To the extent that the following classes of
financial assets and liabilities are not included under direct investment or reserve assets,
other investment includes: (a) other equity; (b) currency and deposits; (c) loans (including
use of IMF credit and loans from the IMF); (d) nonlife insurance technical reserves, life
insurance and annuities entitlements, pension entitlements, and provisions for calls under
standardized guarantees; (e) trade credit and advances; (f) other accounts receivable/
payable; and (g) SDR allocations (SDR holdings are included in reserve assets).

In other words, the "other" category serves as a residual classification that would cover many methods of evading capital controls, such as the use of "leads and lags," which would fall under "trade credit."

Therefore, it seems likely that Chinese foreign exchange reserves have been declining since June 2014 because there has been increased relative demand for foreign assets-decreased demand for the $\mathrm{CNY}$ - as a result of Chinese firms repaying foreign debt and Chinese residents seeking to hold foreign assets. Opinions vary as to the extent to which these outflows represent a broad spectrum of investors selling Chinese assets or whether they reflect Chinese firms reducing their dollar-denominated debt. McCauley and Shu (2016) favor the latter hypothesis. No matter the source of this increased demand, the PBOC has sold foreign exchange reserves to meet this demand for foreign exchange at the desired exchange rate.

How does an increase in relative demand for non-Chinese assets reduce Chinese official foreign exchange reserves? Suppose that Chinese residents purchase dollars from an official exchange bank to travel, buy assets, or pay tuition for their child at a foreign university. 17 The exchange bank would then purchase dollars from the PBOC to replenish its dollar inventory. The exchange bank would use domestic currency, received from the resident, to make this purchase. The PBOC would, in turn, sell some dollar-denominated assets in the open market 
to maintain its desired inventory of dollars. So, to the extent that Chinese residents demand foreign exchange to purchase foreign assets, the decline in Chinese reserves could merely represent a switch in ownership from official to private Chinese portfolios.

Ordinarily, these actions would contract the domestic money supply as the exchange bank would sell CNY to the PBOC in exchange for dollars. If the PBOC took no further action, the domestic money supply would decrease by the amount of the original purchase because the exchange bank used CNY to purchase foreign exchange from the PBOC. When a central bank purchases domestic currency, this reduces the monetary base if it takes no offsetting action. Recall that the PBOC generally does take some offsetting action, however, such as changing reserve requirements or purchasing domestic securities, to "sterilize" the effect of the original foreign currency purchase on the domestic money supply. $\frac{18}{}$ In the absence of sterilization, foreign reserve sales would tighten monetary policy, raise interest rates, and slow the economy.

Since August 2015, however, reserves have often declined less than outside analysts expected (Chang, 2016). There are several possible explanations: (i) The Chinese authorities are simply misrepresenting the changes. (ii) The Chinese authorities are counting CNY that they hold abroad $(\mathrm{CNH})$ as foreign exchange reserves. (iii) The PBOC has been using derivatives to support the $\mathrm{CNY}$ - that is, magnifying current market power with leverage. For example, the PBOC could purchase long forward positions in the CNY or call options, which would tend to support the CNY's current value, without a current outlay of reserves. But when the leveraged positions are unwound - for example, when the PBOC takes delivery of its CNY purchased in the forward contract-then the decline in reserves will be very substantial. Or (iv) reserves may have fallen relatively little because Chinese capital controls may be more effective than anticipated. The Chinese authorities increased capital controls on institutions and private remittances in the fall of 2015 (Ebeling, 2016; Lopez, 2016; and Chang, 2016).

\subsection{Are Chinese Reserves Currently Adequate?}

Are Chinese reserves adequate by international standards? The IMF computes levels of recommended reserves that depend on the exchange rate regime, the effectiveness of capital controls, the quantity of exports, the quantity of short-term foreign debt, other foreign liabilities, and M2. Chen and Orlik (2016) calculate the adequacy of Chinese foreign exchange reserves under alternative assumptions about the effectiveness of Chinese capital controls. If Chinese capital controls are considered to be (relatively) ineffective, then the IMF guidelines recommend \$2.9 trillion foreign exchange reserves for China; and if capital controls are considered (relatively) effective, the IMF guidelines recommend \$1.8 trillion (Chen and Orlik, 2016).

On the other hand, a Deutsche Bank study suggests that measures of reserve adequacy should account for a broad money supply and exports as liabilities of the central bank. By this measure, China's reserves appeared marginally inadequate in the absence of effective capital controls in March 2016. With effective capital controls, then China’s $\$ 3.2$ trillion in reserves (as of March 2016) appear adequate (Baig and Kalani, 2016). 


\section{CHINA'S POLICY CHOICES}

In recent years, China's desired exchange rate target and economic conditions have created a demand for foreign assets that has drained reserves. Although China still has very substantial reserves, if the reserve loss continues indefinitely, then sales will eventually reduce reserves below desired levels and the authorities may have to choose some combination of policies to stem these outflows. This section explains how China could respond to continued capital outflows and how these choices could affect the U.S. economy.

How could China's problems play out? One must note first that it is perfectly possible that positive shocks-for example, an increase in expected growth that raises demand for domestic assets-would solve the problem for the Chinese authorities, eliminating the need for a major policy change. Indeed, the Chinese had some respite in 2016. In the absence of such good luck, the Chinese authorities can choose some combination of the following four policy choices to stem reserve losses:

(i) The authorities could tighten capital controls, using regulations to reduce demand for foreign assets.

(ii) The authorities could use tighter monetary policy (higher interest rates) and/or more expansive fiscal policy to reduce the quantity demanded of foreign assets.

(iii) The authorities could devalue the CNY substantially against a basket of foreign currencies, including the USD.

(iv) The authorities could play for time, continuing to sell off reserves gradually and hoping that conditions improve.

The rest of this section details these options and their implications for the U.S. economy.

\subsection{Tighten Capital Controls}

The Chinese authorities could slow or halt capital outflows by further restricting purchases of foreign assets by Chinese residents. Indeed, Zhang (2016) reports information from several sources that the Chinese authorities have shifted toward such a strategy. The possible regulatory changes listed include measures to restrict investment deals of more than $\$ 10$ billion, certain mergers and acquisitions valued at more than $\$ 1$ billion, and foreign real estate deals by state-owned enterprises involving more than US $\$ 1$ billion.

A strategy centered on tighter capital controls would be aided by the fact that the overall Chinese financial environment is heavily regulated. Even in such a fairly restrictive environment, however, people are ingenious at moving money around and imperfect capital controls tend to become "leakier" over time. For example, trading firms commonly employ "leads and lags," hastening or delaying payments for imports or exports, which implicitly allows them to borrow or lend with their foreign trading partners (Neely, 1999, and Einzig, 1968). If a Chinese exporting firm wished to borrow from abroad, for example, it could request advance payment, for which it would pay its foreign counterpart market interest. As incentives to move capital out of CNY assets grow, individual Chinese residents will become more likely to claim their individual foreign exchange allowances and use the funds to purchase foreign assets. And people will exploit alternative capital outflows that are either legal or are difficult to prevent. 
In deciding how to control capital flows and how strictly to enforce those rules, the Chinese authorities must consider the fact that restricting asset purchases may be politically unpopular, especially with wealthy, well-connected residents. Tightening capital controls would also run counter to the longer-run goal of the Chinese authorities to reduce their financial regulation and increase the international use of the Chinese currency (CNY).

From a global standpoint, economists might be concerned that expanding capital controls would interfere with the efficient allocation of resources, but such costs would be borne almost entirely by Chinese residents. From a strictly U.S. point of view, expansion of Chinese capital controls would have no measurable effect on the U.S. economy, although they may affect portfolio decisions of American firms and individuals who do business with China.

\subsection{Monetary or Fiscal Policy}

The Chinese authorities could reduce or even reverse outflows by some combination of expansionary fiscal or tighter monetary policy. Either method would raise interest rates, which would tend to raise demand for domestic assets and the foreign exchange value of the CNY. Although fiscal policy can be used for substantial policy changes, it is generally too cumbersome to use for day-to-day operations.

To the extent that the Chinese authorities would use monetary policy, the PBOC probably would use a combination of regulatory tools (such as reserve requirement manipulation) and market-based measures (such as open market operations) to influence interest rates. Although the PBOC has been moving away from the use of regulatory measures and toward market tools for monetary policy, it still does change reserve requirements as a policy tool. Tighter monetary policy and expansive fiscal policy have opposite effects on GDP, but both tend to raise domestic interest rates and thereby strengthen the CNY.

A fiscal expansion to accompany the monetary tightening would strengthen the effect on the exchange rate, but the use of fiscal policy also has some disadvantages. Specifically, a significant fiscal expansion would be expensive and increase the Chinese debt-to-GDP ratio, which has already climbed to about 44 percent in recent years, a high level for an emerging market (Trading Economics, 2016). But the government asserts room for further fiscal expansion (Bloomberg News, 2016b). In addition, fiscal policy takes time to formulate and implement and is difficult to adjust rapidly. The slowness and clumsiness of the fiscal instrument means that expansionary fiscal policies usually can only supplement contractionary monetary policy to defend an exchange rate.

A monetary tightening would have the very undesirable side effect of slowing domestic growth. In fact, the PBOC has been easing policy-lowering short-term interest rates-since 2014 in an effort to stimulate growth (Figure 10) (Bloomberg News, 2016b). In the spring of 2016, the PBOC had reportedly been concerned by signs of sluggish economic growth and declines in equity prices (Bloomberg News, 2016b). In view of these concerns, the PBOC took advantage of a fall-off in capital outflows/pressure on the CNY to reduce the required reserves ratio by 50 basis points on March 1, 2015, to maintain liquidity and steady credit growth. $\underline{19}$ The presentation of China's 13th Five-Year Plan for growth and reform at the National People's Congress on March 5, 2015, motivated action prior to this date. Analysts expect further easing 
Figure 10

\section{The People's Bank of China Has Been Easing Policy}

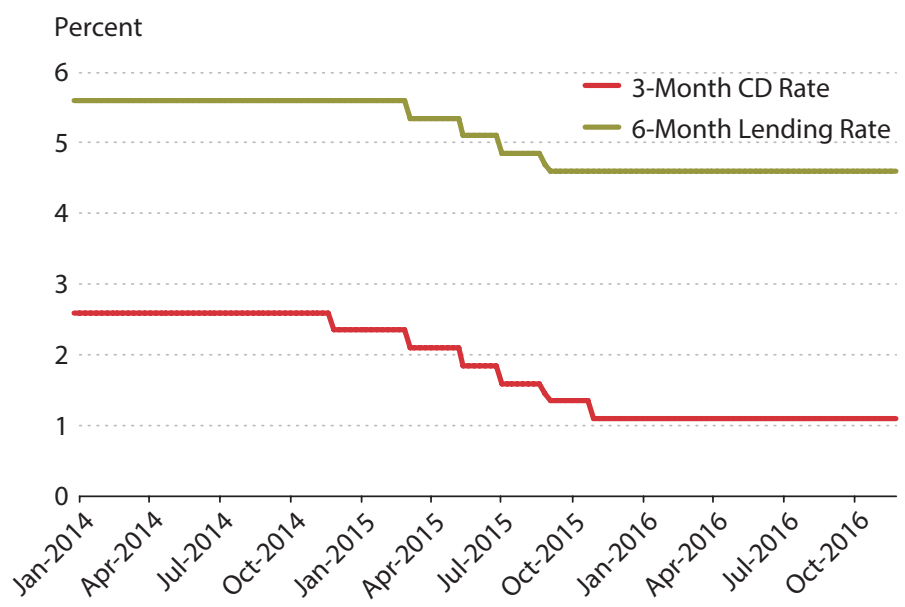

NOTE: The figure displays two short-term Chinese interest rates from January 2014 through November 2016.

SOURCE: PBC, Tullett Prebon Information, National Interbank Funding Center, and Haver Analytics.

in the form of further reductions in benchmark interest rates and reserve ratios. Growth remains a major priority for the Chinese authorities.

Expansionary fiscal and contractionary monetary policy would have offsetting effects on Chinese GDP and therefore demand for U.S. exports. And U.S. exports to China account for only a very small proportion of U.S. output. Therefore, a monetary tightening or an accompanying fiscal expansion would have little direct effect on the United States.

\subsection{Devalue the CNY}

The authorities have been selling reserves to maintain the exchange rate because Chinese firms and residents have been seeking to move their asset holdings to non-CNY assets. Tighter capital controls would seek to prevent markets from making this asset shift. Monetary or fiscal policy would change the fundamentals to make asset demand consistent with the desired exchange rate. Another way to correct the inconsistency, however, would be to change the exchange rate to make it more consistent with fundamentals. Specifically, Chinese authorities could devalue the CNY substantially against a basket of foreign currencies, including the dollar.

This tactic would reduce domestic purchases of foreign assets by making them more expensive in terms of the CNY and presumably reducing expectations of future returns. But if such a devaluation is to reduce fear of future devaluation, it must be substantial; otherwise, it will just increase expectations of future devaluation and increase the rate at which authorities must sell reserves. Indeed, the Chinese authorities have devalued their currency several times recently, in August 2015 and January 2016 (Ebeling, 2016; Bloomberg News, 2016a; China Post, 2016). A small devaluation that simply increases expectations of future devaluations would 
Figure 11

\section{USD Trade Weights}

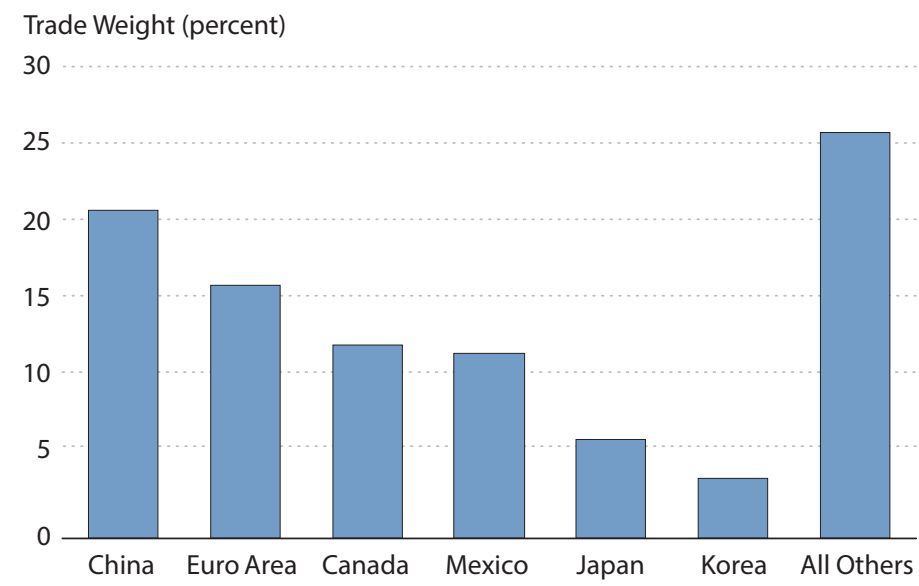

NOTE: The figure displays the currency weights for the trade-weighted USD in 2016.

SOURCE: Board of Governors of the Federal Reserve System.

also increase the demand for foreign assets because a CNY devaluation increases the value of foreign currency assets in terms of the CNY.

From the point of view of the domestic Chinese economy, a devaluation would make Chinese goods less expensive relative to foreign goods, thereby making foreign (including U.S.) industries less competitive with their Chinese counterparts. This would tend to stimulate the Chinese economy, but emerging markets that devalue currencies also often find that such devaluations provoke inflation.

How likely is a large devaluation of the CNY and how would it affect the United States? Using options prices from Bloomberg, one can calculate that, as of September 26, 2016, there was a 22 percent chance of a devaluation of at least 10 percent within one year. The open interest in such options increased substantially in 2016. Of course, such calculations strictly describe only risk-neutral probabilities, which is unlikely to be the case for such a large change in a major currency. $\underline{20}$

Some simple calculations indicate that the trade-weighted USD would be fairly sensitive to CNY movements, with the trade-weighted USD appreciating 0.35 to 1 percent for every 1 percent of CNY depreciation. This calculation uses the currency weights for the USD tradeweighted basket, as well as information about historical correlations in returns of those currencies (Figure 11). The CNY holds a 22 percent share in the trade-weighted USD basket. Some simple calculations with the covariance matrix of historical log returns of trade-weighted currencies imply that a 15 percent devaluation of the CNY would increase the real trade-weighted dollar's value by 8.6 percent. $\underline{21}$ This substantial decline would be an unwelcome shock to U.S. tradable goods industries, making U.S. goods relatively more expensive. Although there is disagreement on the effect of exchange rate changes on trade (Leigh et al., 2015), such a sudden 
devaluation of the $\mathrm{CNY}$ would create some exchange rate instability and modest pain for some U.S. tradable goods industries but would not be a major issue for the U.S. economy as a whole.

An alternative to devaluing the $\mathrm{CNY}$ would be to simply let it float freely-or much more freely than today. Given that Chinese financial markets have become fairly sophisticated, Chinese businesses might find that they could cope with the increase in uncertainty about the future exchange rate much more easily than they could even a few years ago.

\subsection{Defer a Decision and Continue To Sell Off Reserves}

Finally, the Chinese authorities could defer a decision on policy changes by continuing to sell off their foreign exchange reserves to domestic residents, perhaps in conjunction with tighter capital controls. At first glance, this would appear to be a dangerous scenario for the United States. Consider a back-of-the-envelope calculation about the consequences of such a sale for the U.S. yield curve: A sale of the entire Chinese foreign exchange reserve portfolio might dump \$3 trillion worth of developed-country bonds onto the market. This figure would include about \$1.8 trillion in U.S. securities, including \$1.25 trillion worth of Treasury securities and perhaps $\$ 500$ billion of agency and corporate debt. Because the U.S. quantitative easing (QE) episode showed that the bonds of developed countries are close substitutes for each other, one must also account for Chinese sales of \$1.2 trillion in non-U.S. bonds in calculating the effect on U.S. interest rates (Neely, 2015, and Bauer and Neely, 2014).

How much would these sales affect U.S. yields? The accompanying boxed insert explains some very rough calculations that suggest that a sale of the whole $\$ 3$ trillion of Chinese foreign exchange reserves might raise U.S. yields by 20 to 30 basis points along the yield curve. One should note that there is a great deal of uncertainty associated with these estimates and the true effect might be much smaller than 20 basis points or larger than 30 basis points. Such a sale would put pressure on the Federal Open Market Committee (FOMC) to raise U.S. shortterm interest rates at least slightly higher than they would be otherwise.

Such a calculation ignores a couple of important facts, however. First, such a sell-off of Chinese foreign reserves would have very negative valuation effects on the Chinese portfolio, creating a substantial disincentive for it. Nevertheless, it is possible.

Second, if the hypothetical Chinese sales merely reflect a transfer of assets from Chinese authorities to Chinese residents, they might not have any effect at all. That is, when Chinese residents purchase foreign assets for personal savings or Chinese firms repay loans denominated in foreign-currency (i.e., reducing foreign liabilities), the purchases transfer foreign assets from the government to the private sector, reducing Chinese foreign exchange reserves but increasing private asset holdings. It shouldn't matter to the U.S. economy if the PBOC or the Chinese people hold U.S. assets.

Third, the effect of a sale will probably be much smaller than the QE evidence would indicate because a substantial portion of the effect of QE announcements on U.S. interest rates probably occurred because the announcement reduced market participants' expectations of future U.S. monetary policy. That is, the asset purchase announcements "signaled" that U.S. monetary policy would be easier than the public had previously anticipated. A Chinese sale of U.S. assets cannot signal market participants about future Federal Reserve policy. 


\section{How Much Would a Sale of Chinese Foreign Exchange Reserves Drive Up U.S. Yields?}

Researchers have calculated the effect of the Federal Reserve's Large-Scale Asset Purchase (LSAP) program on U.S. bond yields. One would like to use those estimates to create a very rough estimate of the effect of a sale of the whole Chinese foreign exchange reserve portfolio on U.S. yields. These calculations are very rough and have a great deal of uncertainty associated with them but permit a ballpark estimate of the size of the effects.

Neely (2015) estimated the announcement effects of QE1's $\$ 1.725$ trillion bond purchase on 10-year bonds from the United States, Germany, Japan, and the United Kingdom, four countries whose bonds comprise the great majority of foreign exchange reserves. Neely (2015) computed two sets of estimates, one from a smaller set of announcements about LSAPs specifically and one from a larger set of announcements that included all U.S. monetary policy announcements during the QE1 period. The table shows that the estimate of the effect of QE1 on U.S., German, Japanese, and U.K. bond yields.

\section{QE1-Induced Yield Changes on 10-Year Sovereign Bonds by Country (in basis points)}

\begin{tabular}{lccccc} 
Type of announcement & U.S. & Germany & Japan & U.K. & $\begin{array}{c}\text { Average of Germany, } \\
\text { Japan, and the U.K. }\end{array}$ \\
\hline Only LSAP announcements & -94 & -39 & -18 & -43 & -33.3 \\
\hline All FOMC announcements & -60 & -5 & -9 & -21 & -11.7
\end{tabular}

Translating these estimates into estimates of the effect of the sale of Chinese reserves requires some additional assumptions, however, as there are differences between the two actions.

First, we note that the (approximately) $\$ 3$ trillion Chinese foreign exchange portfolio is about 174 percent of the $\$ 1.725$ trillion of QE1. So, the effects must be scaled up by that number. Second, Bauer and Neely (2015) estimate that a considerable portionperhaps half_-of the effect of QE announcements on U.S. and foreign yields came through the "signaling" channel in which yields declined because asset purchase announcements signaled to markets that the FOMC would keep short-term rates lower for longer. Chinese transactions in U.S. assets cannot signal anything about U.S. monetary policy, so we must scale down the estimates by half. Third, the QE purchases were concentrated at the long end of the yield curve, while we assume that the bonds in the Chinese portfolio are more evenly distributed along the curve. Therefore, we cut down the estimated effect by half to account for this dispersion. Finally, we must account for the fact that the effects from sales of non-U.S. bonds will be much smaller than the effects on U.S. bonds. For simplicity, we assume that foreign bonds comprise one-third of the Chinese portfolio and have an effect equivalent to the average effect from German, Japanese, and U.K. bonds shown in the table. Thus, the equations for the point estimate of the effect of a large Chinese sale of foreign exchange reserves across the yield curve would be as follows:

$$
\begin{aligned}
& 1.74^{*} 0.5^{*} 0.5^{*}\left(0.667^{*} 94+0.333^{*} 33.33\right)=32.1 \text { basis points } \\
& 1.74^{*} 0.5^{*} 0.5^{*}\left(0.667^{*} 60+0.333^{*} 11.7\right)=19.1 \text { basis points. }
\end{aligned}
$$

An increase in interest rates of this size would have a measurable effect on the U.S. economy, but the Federal Reserve would likely offset a large part of it and the overall effect would probably be modest.

There are a great many reasons to distrust this calculation. The original estimates of the effects of QE include a lot of uncertainty about the total size of the effect and the contribution of signaling versus portfolio balance and other effects. A given purchase is unlikely to affect short- or medium-term yields in the same way that it would affect long-term yields. The distribution of maturities and currencies of bonds in the Chinese foreign exchange portfolio is unknown and must be estimated.

Furthermore, this example assumes that the Chinese sale is immediate and that it is not simply the result of the PBOC supplying foreign exchange in response to demand from domestic investors. If the Chinese sell reserve assets in response to greater domestic demand for foreign assets, as seems likely in the present case, then this transfer of demand from one party to another will have no effect on foreign yields.

Assuming that the Chinese sale drove prices down immediately, we can also calculate how much such a sale would cost the Chinese. Specifically, the log price and yield of an $n$-year, zero-coupon bond are related as follows: $p=5 \ln (1+y)$. Therefore, an $X$-percentage-point change in the yield of an $n$-year, zero coupon bond will change the price of the bond by $n X$ percent. For example, a 25-basis-point increase in the yield of a 5-year, zero-coupon bond decreases the price of the bond by approximately 1.25 percent. 


\section{CONCLUSION}

Although Chinese GDP growth has been extremely strong for decades, it has fallen off to merely high levels in the past few years. At the same time, Chinese imports and exports have declined somewhat from their 2008 peak. By 2012, analysts were reducing their estimates of Chinese GDP growth, future interest rates, and future demand for the renminbi (CNY). These trends led (mostly) domestic investors to shift their asset holdings from CNY-denominated assets to foreign assets. As a result, the PBOC has been selling foreign exchange and buying the domestic currency to maintain the value of the CNY since June 2014. To support real activity, however, the PBOC has prevented these transactions from reducing the money supply by sterilizing them in the domestic money market.

Although China has very substantial foreign exchange reserves-more than meeting IMF benchmarks-limited capital outflows and devaluation pressure against the CNY continue. The loss of reserves is relatively slow compared with the very large reserves that China retains, but it still cannot go on forever. It is certainly possible that favorable economic shocks will end the loss of reserves before policy must be significantly changed. However, unless such favorable economic shocks end the loss of reserves, China will face a choice among policy alternatives. Specifically, the Chinese authorities must eventually choose some combination of tighter capital controls, tighter monetary policy, more expansive fiscal policy, or a devaluation. Thus, the situation in China creates the potential for a major real appreciation of the USD or a significant increase in U.S. interest rates from an asset sell-off. It is possible that the Chinese capital outflows will affect U.S. monetary policy by slightly increasing the necessity for rate hikes.

Tightening capital controls, by itself, would likely have very little effect outside China and therefore should not be cause for concern for non-Chinese residents.

Devaluing the CNY would probably produce a fair-sized appreciation of the USD on foreign exchange markets. Although the literature on pass-through to net exports finds only very little effect from modest -5 to 20 percent-real exchange rate movements, such an appreciation, would be unwelcome for firms in the U.S. tradables sector.

Deferring a choice in favor of prolonged reserves sales could create substantial volatility in U.S. interest rate markets and very extensive sales of foreign bonds could increase U.S. yields by a few tens of basis points across the yield curve. This very rough calculation is subject to great uncertainty and some caveats. Of course, dumping $\$ 3$ trillion into international securities would have substantial negative valuation effects on the Chinese authorities' portfolio.

In summary, in the absence of the unlikely event of very large, sudden sales of the Chinese authorities' foreign exchange reserves portfolio, the situation in China is unlikely to substantially affect the U.S. economy or monetary policy. 


\section{NOTES}

1 Soros, George. "Soros Says China's Hard Landing Inevitable." ValueWalk, January 22, 2016; http://www.valuewalk.com/2016/01/george-soros-china-crashing/.

2 See Xinyu, Mei. “Op-ed: Think Twice Before Declaring War on Chinese Currency." People's Daily Online, January 27, 2016; http://en.people.cn/n3/2016/0127/c98649-9010063.html.

$\underline{3}$ See Bloomberg News (2016a). The Chinese government posts the most recent public values of their reserves through the following link: http://www.safe.gov.cn/wps/portal/english/Data.

4 Table 3 in IMF (2014) lists hard pegs, soft pegs, floats, and "other managed" as 13.1, 43.5, 34.0, and 9.4 percent of arrangements, respectively, as of April 30, 2014.

5 Fiscal policy also affects exchange rates, and so it would be possible, in principle, to use fiscal policy for this purpose. But in practice, fiscal policy is much too clumsy and slow to use to manage exchange rates.

6 Research on capital controls in developed countries suggests that such controls can alter the composition of capital flows or drive a small, permanent wedge between domestic and offshore interest rates, but they cannot indefinitely sustain inconsistent policies and their effectiveness tends to erode over time as consumers and firms become better at evading the controls (Marston, 1995). Outflow restrictions, in particular, may buy breathing space, but that is all.

7 There is a fair amount of confusion about whether to denote the Chinese currency as the renminbi or the yuan and how to abbreviate it. The currency name is "renminbi," which literally translates as "the people's currency" in Mandarin, and "yuan" is the unit of account. Therefore, prices are quoted in yuan but the name of the currency is the renminbi. The official abbreviation for the currency is CNY, although RMB is commonly used and CNH is used for yuan in offshore accounts (Bajpai, 2015, and HSBC Global Research, 2016).

$\underline{8}$ Starting in August 2015, Chinese authorities began permitting transactions for services and direct investment. Chinese residents may hold foreign currency in onshore accounts. The Chinese authorities have been loosening capital account restrictions since 2012, introducing onshore currency trading in several major foreign currencies.

$\underline{9}$ Fiscal policy also can affect interest rates and therefore influence exchange rate, but fiscal policy is too slow to formulate and implement and too imprecise to use to control day-to-day exchange rate movements.

10 In the presence of free capital flows, a country wishing to maintain a fixed exchange rate must use monetary policy solely for that purpose. McKinnon and Oates (1966) argue that no government can maintain fixed exchange rates, free capital mobility, and have an independent monetary policy; one of the three options must give. This is known as the "incompatible trinity" or the trilemma (Obstfeld and Taylor, 1998). Policymakers wishing to avoid exchange rate fluctuation and retain scope for independent monetary policy must choose to restrict capital flows.

11 China's very high productivity growth complicates discussions of the historical valuation of the real CNY. That is, a common, practical measure of currency over- or undervaluation is to compare the current real exchange rate with historical values of the real exchange rate. But countries with high productivity growth will generally also experience real appreciation of the domestic currency, making their currencies appear overvalued in comparison with their historical distributions. Such real appreciation of the currencies of high-productivity countries is called the Balassa-Samuelson effect. Figure 5 shows that the CNY appreciated in real terms against the JPY and the USD from 2000-2016, partly as a result of the Balassa-Samuelson effect.

12 The PBOC (2010) describes the instruments used by the PBOC to conduct monetary policy, including an interest rate on deposits, reserve requirements, open market operations, repos, bills issued by the central bank, and central bank rediscounting (lending to banks).

13 National savings and the trade balance are intimately linked in that the excess of national savings less national investment equals a nation's current account balance. Therefore, other things equal, countries with high national savings will tend to run current account surpluses. One way to think about this is that a country with a very high domestic savings rate has lower consumption of imports and so tends to import less than it exports.

14 Wen (2011b) argues that China's very high savings rates are due to the fact that China has a very limited social safety net and a limited lending industry. Thus, Chinese households must save a great deal, both to insure themselves against the risk of sickness or old age and to accumulate down payments for durable goods and housing. High savings rates create current account surpluses and capital inflows (i.e., financial account deficits or imports 
of assets). Therefore, Wen (2011b) continues, the reserve accumulation is not a deliberate policy but the natural outgrowth of very high savings rates and income growth in a country with a nascent financial system.

15 Economists refer to savings that are held to respond to emergencies as "precautionary savings." One should note that some Chinese reserves are invested in less liquid assets, such as agency debt and U.S. corporate bonds, making them more difficult to use rapidly.

16 Because Chinese foreign exchange reserves are denominated in USD, it is possible for them to change value with no purchases or sales, simply through the movements of the value of the USD versus other currencies, such as the EUR or JPY, which might be included in the reserves. For example, if the EUR appreciates with respect to the USD, then the value of EUR assets denominated in USD will increase. These valuation effects are typically not large.

17 Although this example assumes that the USD is the foreign currency, the same logic would hold for any non-CNY currency.

18 It is generally believed that sterilized intervention is not very effective in recapturing monetary independence (Edwards, 1998), but this conclusion assumes that capital controls will not be very effective.

19 Reducing the required reserves ratio essentially means that a bank can make more loans for a given amount of deposits. Therefore, reducing the required reserves ratio is functionally equivalent to reducing interest rates.

$\underline{20}$ Risk-neutral probabilities are those that would cause risk-neutral investors to willingly hold assets under market prices. For example, if bookies offer 2-to-1 odds that the Pittsburgh Steelers would beat the Baltimore Ravens in an upcoming game, then the risk-neutral probability that the Steelers will win is 66.67 percent. Because there could be risk associated with making this bet, bettors might assess that the actual chance of this event could be greater or less than 66.67 percent.

21 This calculation uses the covariance matrix of the 2000-16 log returns of the 11 most important currencies in the trade-weighted basket and calculates the expected change in the value of the USD, conditional on a 15 percent devaluation in the CNY.

\section{REFERENCES}

Baig, Taimur and Kalani, Gautam. "Assessing Reserve Adequacy in EM, with a Focus on China." Duetsche Bank Research, March 14, 2016.

Bajpai, Prableen. "Yuan vs. RMB: Understanding the Difference." Investopedia, June 11, 2015, updated March 23, 2016; http://www.investopedia.com/articles/forex/061115/yuan-vs-rmb-understanding-difference.asp.

Bauer, Michael D. and Neely, Christopher J. "International Channels of the Fed's Unconventional Monetary Policy." Journal of International Money and Finance, June 2014, 44, pp. 24-46; https://doi.org/10.1016/j.jimonfin.2013.12.007.

Bloomberg News. "China's Foreign-Exchange Reserves Decline to 3.23 Trillion." Bloomberg News, February 6, 2016a; http://www.bloomberg.com/news/articles/2016-02-07/china-s-foreign-exchange-reserves-decline-to-3-23-trillion.

Bloomberg News. "China Flags Scope for Policy Stimulus, Tweaks Monetary Stance." Bloomberg News, February 25, 2016b; http://www.bloomberg.com/news/articles/2016-02-26/pboc-s-zhou-says-china-still-has-monetaryspace-to-aid-economy.

Bradsher, Keith. "China's Renminbi Is Approved by I.M.F. as a Main World Currency." New York Times, November 30, 2015; https://www.nytimes.com/2015/12/01/business/international/china-renminbi-reserve-currency.html? $\quad \mathrm{r}=0$.

Cendrowski, Scott. “Here's Why China's Currency Will Be Included in the IMF's Basket." Fortune, November 16, 2015; http://fortune.com/2015/11/16/heres-why-chinas-currency-was-included-in-the-imfs-basket/.

Chang, Gordon G. “China's Forex Reserves May Already Be Below IMF Safety Line." Forbes, February 7, 2016; http://onforb.es/1K6Qwxi.

Chen, Fielding and Orlik, Tom. "Something in Reserve? Assessing China's FX Buffer." Bloomberg Professional, February 1, 2016; https://www.bloomberg.com/professional/blog/something-in-reserve-assessing-chinas-fx-buffer/.

China Post. "China Cuts Yuan Fix in Biggest Move Since Devaluation." China Post, June 27, 2016; http://www.chinapost.com.tw/china/chinabusiness//2016/06/27/470491/Chinacuts.htm. 
Ebeling, Paul. "China's Forex Reserves Fell in July, Gold Reserves Up." Live Trading News, August 7, 2016; http://www.livetradingnews.com/chinas-forex-reserves-fell-july-gold-reserves-11327.html\#.WIYvrU0zV9A.

Edwards, Sebastian. "Capital Flows, Real Exchange Rates and Capital Controls: Some Latin American Experiences." NBER Working Paper No. 6800, National Bureau of Economic Research, November 1998; http://www.nber.org/papers/w6800.

Einzig, Paul. Leads and Lags: The Main Cause of Devaluation. London: MacMillan and Company, 1968; https://doi.org/10.1007/978-1-349-00268-9.

Fox News. "Sens. Schumer, Graham Won't Pursue Chinese Tariff Bill." Fox News, September 28, 2006; http://www.foxnews.com/story/2006/09/28/sens-schumer-graham-wont-pursue-chinese-tariff-bill.html.

HSBC Global Research. "Emerging Markets Currency Guide 2016: An Essential Companion." January 2016; http://bg.panlv.net/report/1e1692068457e0b7.html.

International Monetary Fund. Balance of Payments and International Investment Position Manual. Sixth Edition. Washington, DC: IMF, November 2013; http://www.imf.org/external/pubs/ft/bop/2007/bopman6.htm.

International Monetary Fund. Annual Report on Exchange Rate Arrangements and Exchange Restrictions 2014. Washington, DC: IMF, October 2014; https://www.imf.org/external/pubs/nft/2014/areaers/ar2014.pdf.

International Monetary Fund. "Statement by Ms. Christine Lagarde on IMF Review of SDR Basket of Currencies." Press Release No. 15/513, November 13, 2015; http://www.imf.org/external/np/sec/pr/2015/pr15513.htm.

Leigh, Daniel; Lian, Weicheng; Poplawski-Ribiero, Marcos and Tsyrennikov, Viktor. "IMF Survey: Exchange Rates Still Matter for Trade." World Economic Outlook, September 28, 2015; https://www.imf.org/en/News/Articles/2015/09/28/04/53/sores092815b.

Lopez, Linette. “There's a Part of China's Economy That's Making Less Sense Every Day." Business Insider, July 11, 2016; http://www.businessinsider.com/china-yuan-outflows-make-no-sense-2016-7.

Marston, Richard C. International Financial Integration: A Study of Interest Differentials between the Major Industrial Countries. New York: Cambridge University Press, 1995.

McCauley, Robert N. and Shu, C. "Dollars and Remnibi Flowed Out of China." BIS Quarterly Review, March 6, 2016, pp. 26-27; https://www.bis.org/publ/qtrpdf/r_qt1603u.htm.

McKinnon, Ronald I. and Oates, Wallace E. "The Implications of International Economic Integration for Monetary, Fiscal and Exchange Rate Policies." The International Finance Section, Princeton University, 1966.

Minton, Zanny. "Global Finance Survey: A Wealth of Blueprints." Economist, January 30, 1999, pp. S5-S8.

Neely, Christopher J. "The Giant Sucking Sound: Did NAFTA Devour the Mexican Peso?" Federal Reserve Bank of St. Louis Review, July/August 1996, 78(5), pp. 33-48; https://files.stlouisfed.org/files/htdocs/publications/review/96/07/9607cn.pdf.

Neely, Christopher J. "An Introduction to Capital Controls." Federal Reserve Bank of St. Louis Review, November/ December 1999, 81(6), pp. 13-30; https://files.stlouisfed.org/files/htdocs/publications/review/99/11/9911cn.pdf.

Neely, Christopher J. "Unconventional Monetary Policy Had Large International Effects." Journal of Banking and Finance, March 2015, 52, pp. 101-11; https://doi.org/10.1016/j.jbankfin.2014.11.019.

Obstfeld, Maurice and Taylor, Alan M. "The Great Depression as a Watershed: International Capital Mobility Over the Long Run," in Michael D. Bordo, Claudia D. Goldin, and Eugene N. White, eds., The Defining Moment: The Great Depression and the American Economy in the Twentieth Century. Chicago: University of Chicago Press, 1998, pp. 353-402.

People's Bank of China. "Central Bank Instruments to Deal with the Crisis—From the Perspective of the People's Bank of China," in The Global Crisis And Financial Intermediation In Emerging Market Economies, BIS Papers No. 24. Basil: Bank for International Settlements, December 2010, pp. 131-32; http://www.bis.org/publ/bppdf/bispap54.pdf.

Spiegel, Mark M. "A Look at China's New Exchange Rate Regime." Federal Reserve Bank of San Francisco Economic Letter, No. 2005-23, September 9, 2005; http://www.frbsf.org/economic-research/publications/economic-letter/2005/september/a-look-at-china-new-exchange-rate-regime/. 
Trading Economics. "China Government Debt to GDP." 2016; http://www.tradingeconomics.com/china/government-debt-to-gdp.

Wen, Yi. "Making Sense of China's Excessive Foreign Reserves." Working Paper No. 2011-006A, Federal Reserve Bank of St. Louis, February 2011a; https://research.stlouisfed.org/wp/more/2011-006.

Wen, Yi. "Explaining China's Trade Imbalance Puzzle." Working Paper No. 2011-018A, Federal Reserve Bank of St. Louis, August 2011b; https://research.stlouisfed.org/wp/2011/2011-018.pdf.

Wigglesworth, Robin; Lewis, Leo and McCrum, Dan. "Central Banks: Negative Thinking." Financial Times, February 17, 2016; https://www.ft.com/content/7333e92a-d4a2-11e5-829b-8564e7528e54.

Wildau, Gabriel. "China's Large Forex Reserves Constitute Both a Blessing and a Curse." Financial Times, September 29, 2014; https://www.ft.com/content/9dfa88ce-2ea1-11e4-afe4-00144feabdc0.

Wildau, Gabriel. “China Steps Up Capital Controls To Stem Outflows.” Financial Times, January 8, 2016a; https://www.ft.com/content/9e25a772-b5df-11e5-aad2-3e9865bc6644.

Wildau, Gabriel, "China Mouthpiece Warns Soros Against Shorting Renminbi." Financial Times, January 26, 2016b; http://www.ft.com/intl/cms/s/0/ebabbebec40d11e5993ad18bf6826744.html\#axzz46C17ktCF.

Xiao, Fengjuan and Kimball, Donald. "Effectiveness and Effects of China's Capital Controls." Conference: WTO, China, and the Asian Economies, IV: Economic Integration and Economic Development, University of International Business and Economics, Beijing, China, June 2006; https://faculty.washington.edu/karyiu/confer/beijing06/papers/xiao-kimball.pdf.

Zhang, Maggie. "China's Foreign Investment 'Shopping Spree' Over as Beijing Moves To Slash Capital Outflow." South China Morning Post, November 29, 2016; http://www.scmp.com/news/china/economy/article/2050029/ chinas-foreign-investment-shopping-spree-over-beijing-moves-slash. 
